\title{
Uji Kualitatif Aktivitas Antioksidan Ekstrak Etanol Propolis
}

\author{
Marilis Rosana ${ }^{\mathrm{a}, 1}$, Ahwan $^{\mathrm{a}, 2}$, Fadilah Qonitah ${ }^{\mathrm{a}, 3^{*}}$ \\ a Program Studi Farmasi, Fakultas Sains Teknologi dan Kesehatan, Universitas Sahid Surakarta, J1. Adi Sucipto No. I54, Jajar, Laweyan, \\ Surakarta, Jawa Tengah 57I44 \\ 1elrosana79@gmail.com;2ahwan@usahidsolo.ac.id; ${ }^{3}$ fadilahqonitah@usahidsolo.ac.id* \\ *korespondensi penulis
}

\begin{tabular}{ll}
\hline INFO ARTIKEL & ABSTRAK \\
\hline $\begin{array}{l}\text { Diterima : } \\
\text { I7-07-202I }\end{array}$ & Propolis adalah zat yang terdiri dari campuran resin, serbuk sari dan lilin tanaman \\
Direvisi : & yang dikumpulkan oleh lebah madu. Selain itu propolis mengandung senyawa \\
OI-08-202I & metabolit sekunder seperti flavonoid yang berpotensi sebagai antioksidan. Penelitian \\
Disetujui : & ini dilakukan dengan tujuan untuk mengetahui ada atau tidaknya potensi antioksidan \\
OI-08-202I & dari ekstrak etanol propolis. Uji kualitatif aktivitas antioksidan ekstrak etanol \\
& propolis dilakukan menggunakan pereaksi DPPH (2.2-diphenyl-I-picrylhydrazy $).$ \\
\hline Kata kunci: & Hasil penelitian menunjukkan bahwa terjadi perubahan warna larutan DPPH dari \\
Antioksidan; & unggu menjadi kuning pada ekstrak etanol propolis panen 6 bulan dan I tahun. \\
Propolis; & Berdasarkan hasil tersebut dapat disimpulkan bahwa ekstrak etanol propolis panen \\
DPPH. & 6 bulan dan I tahun memiliki potensi sebagai antioksidan.
\end{tabular}

DPPH.

Key word:

Antioxidant;

Propolis;

$\mathrm{DPPH}$

\begin{abstract}
Propolis is a substance consisting of a mixture of resin, pollen, and plant wax collected by honeybees. In addition, propolis contains secondary metabolite compounds such as flavonoids that have the potential as antioxidants. This research was conducted to know the potential or potential antioxidants of propolis ethanol extract. A qualitative test of antioxidant activity of propolis ethanol extract was conducted using DPPH reagents (2.2-diphenyl-I-picrylhydrazyl). The results showed that there was a discoloration of DPPH solution from Purple to yellow in propolis ethanol extract harvested 6 months and I year. Based on these results can be concluded that propolis ethanol extract harvest 6 months and I year has the potential as an antioxidant.
\end{abstract}

This is an open access article under the CC-BY-SA license.

\section{Pendahuluan}

Radikal bebas merupakan molekul yang mengandung elektron yang tidak berpasangan dan bersifat sangat reaktif. Radikal bebas akan bereaksi dengan senyawa yang ada disekelilingnya untuk mendapatkan pasangan elektron bebas sehingga mencapai kestabilan. Jika radikal bebas masuk ke dalam tubuh akan bereaksi dan merusak sel tubuh sehingga dapat menimbulkan berbagai penyakit (Hesti Kurnia \& Taufikurohmah, 2017). Oleh karena itu diperlukan suatu senyawa yang dapat meredam radikal bebas.

Senyawa yang dapat menghentikan atau memutus reaksi berantai radikal bebas adalah senyawa antioksidan. Antioksidan dapat menyumbangkan satu atau lebih elektronnya sehingga radikal bebas dapat diredam. Tubuh kita menghasilkan antioksidan akan tetapi tidak cukup untuk meredam radikal bebas yang masuk ke tubuh
(Pratama et al., 2018). Oleh karena itu diperlukan asupan antioksidan dari luar tubuh atau eksogen.

Antioksidan eksogen dapat diperoleh dari sumber alami maupun sintetik. Adanya kekhawatiran akan penggunaan antioksidan sintetik mendorong penelitian untuk mencari sumber antioksidan alami yang dapat berasal dari tanaman buah-buahan, madu propolis, lilin lebah, royal jelly dan polen (Mahantesh et al., 2012).

Propolis atau dikenal dengan sebagai lem lebah merupakan zat yang terdiri dari campuran resin, serbuk sari dan lilin tanaman yang dikumpulkan oleh lebah madu dari berbagai tanaman. Propolis dan ekstrak propolis sudah banyak diaplikasikan untuk mengobati penyakit karena manfaatnya sebagai antiseptik, antiinflamasi, antioksidan, antibakteri, antijamur, antikanker dan imunomodulator (Pasupuleti et al., 2017). 
Propolis mentah terdiri dari komposisi senyawa diantaranya $50 \%$ resin, 30\% lilin, I0\% minyak esensial, $5 \%$ pollen, dan $5 \%$ mineral dan senyawa oragik lainnya. Senyawa organik yang penting dalam propolis diantaranya fenolik, ester, flavonoid, betasteroid, aldehid aromatik dan alkohol (Huang et al., 20I4). Senyawa polifenol terutama flavonoid dalam propolis dapat memberikan efek sebagai antioksidan (Dai \& Mumper, 2010).

Penelitian yang dilakukan oleh Thamrin et al., (2016) melaporkan bahwa ekstrak dan fraksi propolis lebah trigona inca mempunyai aktivitas antioksidan. Selain itu penelitian lain melaporkan bahwa ekstrak propolis air, etanol dan metanol positif mengandung senyawa alkaloid, flavonoid, fenolik dan tannin serta mempunyai aktivitas antioksidan yang lemah (Khairunnisa et al., 2020).

Berdasarkan uraian tersebut diperlukan informasi mengenai kandungan propolis dari berbagai daerah maupun yang dipanen dalam waktu yang berbeda. Oleh karena itu penelitian ini dilakukan untuk mengetahui aktivitas antioksidan dari ekstrak propolis berdasarkan waktu panen dengan menggunakan metode DPPH (2,2Diphenyl-I-picrylhydrazyl) secara kualitaf.

\section{Metode}

\section{Alat dan Bahan}

Alat-alat yang digunakan dalam penelitian ini diantaranya alat-alat gelas (pyrex), timbangan analitik (acys), rotary evaporator (bio base), dan oven (marnert).

Bahan-bahan yang digunakan dalam penelitian ini adalah propolis yang dipanen 6 bulan dan I tahun asal Desa Alastuwo Magetan untuk dijadikan ekstrak propolis, etanol 96\% (Medika), etanol P.a (Emsure) dan DPPH (2,2-Diphenyl-I-picrylhydrazyl ) (Merck).

\section{Jalannya Penelitian Persiapan Sampel Penelitian}

Sebanyak masing-masing I kg propolis yang baru dipanen 6 bulan dan I tahun dipotong menjadi ukuran lebih kecil, dikeringkan di bawah sinar matahari sehingga menjadi simplisia. Hasil simplisia propolis dihaluskan sehingga diperoleh serbuk simplisia propolis.

\section{Pembuatan Ekstrak}

Sebanyak masing-masing 200 gram simplisia propolis direndam dengan etanol $96 \%$ dengan perbandingan I:5. Selanjutnya direndam selama 7 hari sambil sesekali diaduk. Hasil rendaman kemudian disaring dan filtratnya diuapkan dengan rotary evaporator pada suhu $60^{\circ} \mathrm{C}$ sampai diperoleh ekstrak kental. Selanjutnya ekstrak kental diamati secara organoleptik dan disimpan dialmari pendingin untuk persiapan uji kualitatif aktivitas antioksidan dan dihitung rendemennya dengan rumus sebagi berikut:

Rendemen: $\frac{\text { (Bobot akhir ekstrak propolis) }}{\text { Bobot awal propolis }} \times 100 \%$

Pembuatan Larutan DPPH (2,2-Diphenyl-Ipicrylhydrazyl)

Sebanyak 15,7 mg DPPH dilarutkan dalam IOO mL etanol Pa. sehingga diperoleh larutan DPPH dengan konsentrasi 0,4mM (Qonitah \& Ahwan, 2018).

\section{Uji Kualitatif Aktivitas Antioksidan dengan Metode $\mathrm{DPPH}$}

Sebanyak I mL larutan sampel dimasukkan ke dalam tabung reaksi kemudian ditambahkan $4 \mathrm{~mL}$ larutan DPPH 0,4 mM sedikit demi sedikit dan amati perubahan warnanya. Adanya antioksidan ditandai dengan perubahan warna larutan dari ungu menjadi kuning (Rahmawati et al., 2016).

\section{Hasil dan Pembahasan}

Propolis mengandung senyawa kimia yang bervariasi diantaranya flavonoid, fenolik, terpenoid, gula, hidrokarbon dan mineral (Huang et al., 2014). Senyawa flavonoid dan fenolik yang terkandung dalam propolis tersebut berpotensi sebagai antioksidan. Dalam penelitian ini uji kualitatif aktivitas antioksidan dilakukan dengan metode DPPH. Alasan pemilihan metode ini karena metode DPPH sederhana, cepat, mudah, dan hanya memerlukan sedikit sampel (Astiti Asih et al., 2012). Sampel propolis yang digunakan dalam penelitian ini adalah propolis mentah yang dipanen 6 bulan dan I tahun dari peternak lebah madu asal Desa Alastuwo Magetan Jawa Timur.

\section{Pembuatan Ekstrak Propolis}

Dalam penelitian ini ekstrak etanol propolis dibuat dengan metode ekstraksi maserasi. Tahap persiapan yang dilakukakan sebelum dilakukan maserasi adalah pengeringan, pengahalusan dan perendaman dengan pelarut (Nn, 20I5). Sebelum dilakukan proses ekstraksi, propolis mentah dikeringkan dan dibersihkan terlebih dahulu. Selanjutnya propolis dipotong kecil dan dihaluskan untuk selanjutnya dimaserasi dengan etanol 96\%.

Metode ekstraksi maserasi digunakan dalam penelitian ini karena prosedur dan peralatan yang digunakan sederhana. Selain itu dalam metode maserasi tidak ada pemanasan sehingga bahan alam atau senyawa yang terkandung tidak akan terurai 
(Dwi \& Syam, 2017). Nilai rendemen ekstrak etanol propolis dapat dilihat pada tabel $\mathrm{I}$.

Tabel I. Hasil rendemen ekstrak etanol propolis

\begin{tabular}{|c|c|c|c|}
\hline Sampel & $\begin{array}{c}\text { Berat } \\
\text { propolis( } \\
\text { gram })\end{array}$ & $\begin{array}{c}\text { Berat } \\
\text { ekstrak( } \\
\text { gram) }\end{array}$ & $\begin{array}{c}\text { Rendemen } \\
(\%)\end{array}$ \\
\hline $\begin{array}{l}\text { Propolis } \\
\text { panen } \\
\text { bulan }\end{array}$ & 200 & 4,53 & 2,27 \\
\hline $\begin{array}{l}\text { Propolis } \\
\text { panen } \\
\text { tahun }\end{array}$ & 200 & 7,63 & 3,82 \\
\hline
\end{tabular}

Berdasarkan tabel I menunjukkan bahwa propolis yang dipanen I tahun menghasilkan rendemen ekstrak yang lebih tinggi sebesar 3,82\% dibandingkan dengan propolis yang dipanen 6 bulan dengan rendemen sebesar 2,27\%. Hal ini menunjukkan bahwa propolis yang dipanen I tahun lebih baik daripada propolis yang dipanen 6 bulan untuk menghasilkan rendemen yang lebih tinggi. Hal ini karena semakin lama waktu panen maka kandungan zat aktif yang terbentuk semakin banyak sehingga rendemen semakin tinggi (Nica Dewi et al., 2016)

Ekstrak etanol propolis yang dihasilkan kemudian diuji organoleptik, dihasilkan ekstrak etanol propolis panen 6 bulan dan I tahun bewarna cokelat tua, berasa pahit dan berbau khas aromatik propolis. Pada umumnya propolis bewarna kuning sampai coklat tua sesuai dengan asal resinnya (Yarlina et al., 2020). Ekstrak etanol propolis dalam penelitian ini bewarna coklat tua, semakin gelap warna propolis menunjukkan adanya senyawa flavonoid (Bankova et al., 20I4).

\section{Uji Kualitatif Aktivitas Antioksidan dengan Metode $\mathrm{DPPH}$}

Uji kualitatif aktivitas antioksidan dalam penelitian ini dilakukan dengan metode DPPH. Metode ini dapat menentukan aktivitas antioksidan suatu sampel berdasarkan kemampuannya dalam menangkal radikal DPPH (Rahmawati et al., 2016). Radikal DPPH merupakan suatu senyawa organik mengandung atom nitrogen yang elektronnya tidak berpasangan sehingga tidak stabil dan larutannya bewarna ungu. Radikal DPPH tersebut akan tereduksi dan terjadi pemudaran warna menjadi kuning ketika bereaksi dengan senyawa antioksidan (Astiti Asih et al., 2012).

Aktivitas antioksidan ekstrak etanol propolis panen 6 bulan dan I tahun secara kualitatif ditentukan dengan cara mereaksikan $\mathrm{I} \mathrm{mL}$ larutan sampel dengan $4 \mathrm{~mL}$ larutan DPPH 0,4 mM. Hasil uji kualitatif aktivitas antioksidan ekstrak etanol propolis ditunjukkan pada tabel 2 .
Tabel 2. Hasil uji kualitatif aktivitas antioksidan ekatrak etanol propolis

\begin{tabular}{lcc}
\hline \multicolumn{1}{c}{ Sampel } & $\begin{array}{c}\text { Uji kualitatif } \\
\text { (DPPH 0,4mM+ sampel) }\end{array}$ & Hasil \\
\hline $\begin{array}{l}\text { Ekstrak etanol } \\
\text { propolis panen } 6\end{array}$ & kuning & $(+)$ \\
bulan & & \\
\hline $\begin{array}{l}\text { Ekstrak etanol } \\
\text { propolis panen I } \\
\text { tahun }\end{array}$ & kuning & $(+)$ \\
\hline
\end{tabular}

Berdasarkan tabel 2 menunjukkan bahwa ekstrak etanol propolis panen 6 bulan dan I tahun positif mengandung senyawa antioksidan. Hal ini ditunjukkan dari perubahan warna larutan DPPH dari ungu memudar menjadi kuning. Pemudaran warna ini menunjukkan bahwa radikal DPPH diredam oleh antioksidan yang ada dalam sampel. Atom Nitrogen pada DPPH yang elektronya tidak berpasangan direduksi oleh senyawa yang dapat mendonorkan antom hidrogennya sehingga radikal DPPH menjadi senyawa nonradikal yang stabil (Yulia et al., 20I5). Adapun reaksi radikal DPPH dengan suatu senyawa antioksidan dapat dilihat

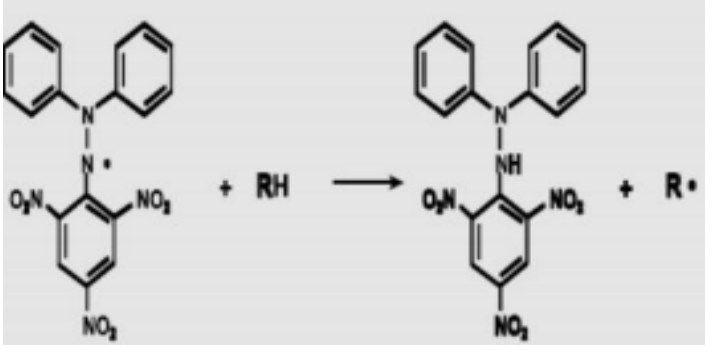

pada gambar I.

Gambar I. Reaksi DPPH dengan senyawa antioksidan (Sami \& Rahimah, 2015)

Aktivitas antioksidan dalam ekstrak etanol propolis dalam penelitian ini dapat berasal dari senyawa fenolik dan flavonoid. Berdasarkan penelitian Huang et al., ( 2014) melaporkan bahwa propolis mengandung senyawa kimia yang bervariasi diantaranya flavonoid, fenolik, terpenoid, gula, hidrokarbon dan mineral.

\section{Simpulan dan Saran}

Berdasarkan uji kualitatif aktivitas antioksidan dengan metode DPPH menunjukkan bahwa ekstrak etanol propolis yang dipanen 6 bulan dan I tahun mempunyai aktivitas antioksidan yang ditunjukkan dengan perubahan warna larutan DPPH dari unggu memudar menjadi kuning.

Berdasarkan penelitian yang telah dilakukan perlu dilakukan studi lanjut terkait pengukuran aktivitas antioksida dari ekstrak etanol propolis secara kuantitatif. 


\section{Daftar Pustaka}

Astiti Asih, I., Ratnayani, K., \& Swardana, I. (20I2). Isolasi Dan Identifikasi Senyawa Golongan Flavonoid Dari Madu K Elengkeng (Nephelium Longata L.). Jurnal Kimia, 6(I), 72-78.

Bankova, V., Popova, M., \& Trusheva, B. (2014). Propolis volatile compounds: Chemical diversity and biological activity: A review. Chemistry Central Journal, 8(I), I-8.

Dai, J., \& Mumper, R. J. (2010). Plant phenolics: Extraction, analysis and their antioxidant and anticancer properties. Molecules, I5(I0), 73I3-7352.

Dwi, A., \& Syam, L. (2017). Kadar Fenolik Total Ekstrak Etanol Daun Kersen (Muntingia Calabura). Jurnal Ilmiah Cendekia Eksakta, I8.

Hesti Kurnia, N., \& Taufikurohmah, T. (20I7). Pengaruh Penambahan Nanosilver Terhadap Aktivitas Antioksidan Nanogold Dalam Meredam Radikal Bebas. UNESA Journal of Chemistry, 6(3), I6I-I65.

Huang, S., Zhang, C. P., Wang, K., Li, G. Q., \& Hu, F. L. (20I4). Recent advances in the chemical composition of propolis. Molecules, I9(I2), I96I0-I9632.

Khairunnisa, K., Mardawati, E., \& Putri, S. H. (2020). Karakteristik Fitokimia dan Aktivitas Antioksidan Ekstrak Propolis Lebah Trigona Sp. Jurnal Industri Pertanian, 2(I), 124-129.

Mahantesh, S. P., Gangawane, A. K., \& Patil, C. S. (20I2). Free Radicals , Antioxidants , Diseases and Phytomedicines in Human Health : Future Perspects. World Research Journal of Medicine \& Aromatic Plants, I(I), 6-IO.

Nica Dewi, P., Hartiati, A., \& Mulyani, S. (2016). Pengaruh Umur Panen Dan Tingkat Maserasi Terhadap Kandungan Kurkumin Dan Aktivitas Antioksidan Ekstrak Kunyit (Curcuma Domestica Val.). Jurnal Rekayasa Dan Manajemen Agroindustri, 4(3), I05I I5.

Nn, A. (2015). A Review on the Extraction Methods Use in Medicinal Plants, Principle, Strength and Limitation. Medicinal \& Aromatic Plants, O4(03), 3-8.

Pasupuleti, V. R., Sammugam, L., Ramesh, N., \& Gan, S. H. (2017). Honey, Propolis, and
Royal Jelly: A Comprehensive Review of Their Biological Actions and Health Benefits. Oxidative Medicine and Cellular Longevity, 2017.

Pratama, M., Muflihunna, A., \& Octaviani, N. (2018). Analisis Aktivitas Antioksidan Sediaan Propolis Yang Beredar Di Kota Makasar dengan Metode FRAP (Ferric Reducing Antioxidant Power). Jurnal Ilmiah As-Syifaa, IO(I), I I-I8.

Qonitah, F., \& Ahwan. (2018). Aktivitas Antioksidan Dan Kandungan Fenolik Total Dari Isolat Polar Fraksi Heksana Ekstrak Etanol Daun Sirih (Piper Betle L.). Jurnal Farmasetis, 7(2), 42-46.

Rahmawati, R., Muflihunna, A., \& Sarif, L. M. (2016). Analisis Altivitas Antioksidan Produk Sirup Buah mengkudu (Morinda citrifolia L.) Dengan Metode DPPH. Jurnal Fitofarmaka Indonesia, 2(2), 97-IOI.

Sami, F. J., \& Rahimah, S. (2015). Uji Aktivitas Antioksidan Ekstrak Metanol Bunga Brokoli (Brassica oleracea L. var. Italica) Dengan Metode DPPH (2,2 diphenyl-Ipicrylhydrazyl) dan Metode ABTS (2,2 azinobis (3-etilbenzotiazolin)-6-asam sulfonat). Jurnal Fitofarmaka Indonesia, 2(2), I07-IIO.

Thamrin, A., Erwin, \& Syafrizal. (2016). Uji Fitokimia, Toksisitas Serta Antioksidan Ekstrak Propolis Pembungkus Madu Lebah Trigona Incisa Dengan Metode 2 , 2- diphenyl -I- picrylhidrazyl (DPPH). Jurnal Kimia Mulawarman, I4(I), 54-60.

Yarlina, V. P., Sumanti, D. M., Sofiah, B., \& Mahani. (2020). Kajian Konsentrasi Etanol, Metode Ekstraksi Propolis Dan Karakteristik Ekstrak Propolis Lebah Trigona Sp. Terhadap Aktivitas Antimikroba Escherichia Coli. Jurnal Teknologi \& Industri Hasil Pertanian, 25(I), 27-34.

Yulia, R., Azminah, A., Michella, M., \& Tanzil, A. (2015). An Assay of Antioxidant Power of Methanolic Extract Various Type of Soybean. Jurnal Sains Farmasi \& Klinis, I(2), 122. 